\title{
HABILITAČNÍ ŘEČ
}

\author{
Je št'astný život mravný? \\ (Několik poznámek k Aristotelovu pojetí štěstí) ${ }^{\mathrm{i}}$ \\ Štěpán Špinka
}

\section{Návraty $k$ antickým kořenům}

Antická etika zažila v druhé polovině dvacátého století nebývalou renesanci. Opakovaně se totiž ukázalo, že může sloužit nejen jako inspirace při promýšlení aktuálních morálních problémů, ale také jako korektiv jednostrannosti hlavních novověkých etických rozvrhů, tedy utilitarismu na straně jedné a kantovsky orientované etiky povinnosti na straně druhé. Kromě Platóna a některých škol helénistické filosofie hrál $v$ této renesanci důležitou roli zejména Aristotelés.

Návrat k Aristotelovi přinesl plody především ve dvou oblastech. V angloamerické filosofii to byl zejména obnovený zájem o „etiku ctností“, tedy o takové rozvrhy

\footnotetext{
i Předkládaný text je až na drobné změny totožný s textem habilitační přednášky přednesené v červnu 2011 na Filozofické fakultě UK v Praze. S radostí i vděčností jej věnuji památce doc. Milana Mráze. Spoléhám přitom na jeho pověstnou dobrotu a doufám, že mi i takto po smrti odpustí mnohá zjednodušení a troufalost následujících řádek.
} 
etiky, jejichž centrem není otázka „Jak máme v dané situaci jednat?“, ale „Kým máme být?“ či „Jakým člověkem se máme stávat?“ $\mathrm{Na}$ kontinentu se pak pod vlivem fenomenologické a hermeneuticky orientované filosofie rozvinul intenzivní zájem o Aristotelovu koncepci praktické rozumnosti (fronésis) jako typicky lidské racionality, kterou je zapotřebí odlišit jak od čistě teoretického, tak od instrumentálního „technického“ vědění a která by mohla sloužit jako základ novému porozumění specificky lidského konečného způsobu bytí.

Předkládaný text se soustředí na třetí zajímavý rys Aristotelovy etiky, totiž na její zaměření na štěstí či blaženost (eudaimonia). Pokusí se ve velké stručnosti načrtnout některé hlavní rysy Aristotelovy koncepce blaženosti a představit tuto koncepci jako cestu, která se vyhýbá extrémům utilitaristického hedonismu i vyhroceného kantovství a snaží se dostát víceznačnosti a obtížné uchopitelnosti lidského štěstí.

Následující text je tak možné pochopit dvojím způsobem. V prvním plánu je historicko-filosofickou črtou a stručným prŕspěvkem do rozhovoru mezi dnešním a antickým myšlením. V druhém plánu je pak pokusem zvážit možnost, zda ona na první pohled beznadějně neuchopitelná mnohoznačnost slova „štěsti““, která se zdá každý pokus o jeho teoretické vystižení předem odsuzovat k vždy poněkud trapnému neúspěchu, nakonec nevypovídá cosi velmi podstatného o nás a o našich životech. 


\section{Blaženost a ctnost}

Aristotelova etická pojednání, tedy Etika Nikomachova, Etika Eudémova a Magna Moralia, vycházejí obdobně jako jeho Metafyzika, Fyzika a biologické spisy z teleologicky zaměřeného pojetí skutečnosti. Proto také Stagirita začíná svůj hlavní etický spis, Etiku Nikomachovu, známým tvrzením, že nejen každé umění, věda a jednání míŕi $\mathrm{k}$ nějakému dobru, ale že také celý náš život míří k cíli, který mu propůjčuje tvar a smysl, a který tak hraje roli „nejvyššího dobra“. ${ }^{i}$

Tento předpoklad jednotného zaměření lidského života není samozřejmý a podle Aristotela mu také dobře rozumí pouze ti, kteří berou svůj život vážně a snaží se ho skutečně jakožto jednotný celek utvářet. Přesto se však téměř všichni shodnou na jménu tohoto dobra. Každý totiž nakonec podle Aristotela touží po štěstí či po blaženosti (eudaimonia). ${ }^{\text {ii }}$ Zásadní rozdíly však panují v tom, co touto blažeností či štěstím míníme. Pro jedny spočívá eudaimonia ve slasti, pro druhé ve slávě, jiní ji nacházejí ve vědění a teoretickém poznávání. ${ }^{\text {iii }}$

Podle Aristotela nakonec blaženost nemůžeme hledat nikde jinde než v uskutečnění našich nejvlastnějších možností. Či přesněji, jeho terminologií vyjádřeno: eudaimonia je uskutečnění (energeia) duše co do její skvělosti či ctnosti

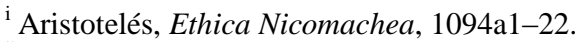

ii Ibid., 1095a14-20.

iii Ibid., 1095a20-1096a10.
} 
(areté) na základě toho, co je člověku nejvlastnější, tedy rozumu (logos). Protože však ctností může být více, je blaženost uskutečněním duše co do její nejdokonalejší ctnosti. A protože je eudaimonia formou celého života, může jí být pouze takové uskutečnění našich možností, které určuje a završuje celý náš život, nikoli pouze jednotlivé jednání či přechodný postoj.

Tak jako na jiných místech svých spisů, také v těchto úvahách Aristotelés postupuje za pomoci metody, kterou př́ležitostně nazývá „dialektickou“ a která sestává ze tři kroků. V prvním z nich Aristotelés kriticky prozkoumává obecně sdílená mínění o diskutovaném problému. To v našem prípadě znamená výčet a odmítnutí výše zmíněných představ o blaženosti. ${ }^{\text {ii }}$

V druhém kroku pak Aristotelés za pomoci svých základních ontologických rozlišení (např. mezi látkou a formou či potencí a aktem) a myšlenkových schémat formuluje vlastní stanovisko $\mathrm{k}$ diskutovanému problému. ${ }^{\mathrm{iii}}$ V našem případě se tento druhý krok nejjasněji projevuje $\mathrm{v}$ Aristotelově úvaze o lidském ergon, tedy „díle“ či „úkolu“, ze šesté kapitoly první knihy Etiky Nikomachovy. ${ }^{\text {iv }}$ V nejstručnější podobě postupuje tato úvaha takto: Člověk je živá bytost. A protože principem života, tedy „prvním uskutečněním“ (entelecheia) a nositelem všech dalších, na

\footnotetext{
${ }^{\mathrm{i}}$ Ibid., 1098a16-18.

ii Ibid., 1095a20-1097a14.

iii Ibid., 1097a15-1098a20.

iv Ibid., 1097b24-1098a18.
} 
toto uskutečnění navazujících potencialit živé bytosti je duše, musíme blaženost hledat $\mathrm{v}$ jejím uskutečnění (tedy $\mathrm{v}$ energeia tés psychés). Protože se však člověk od ostatních živých bytostí liší svým rozumem (je zóon logon echon), musí jeho blaženost spočívat $\mathrm{v}$ uskutečnění rozumu $\mathrm{v}$ různých sférách naší lidské bytosti.

Ve třetím kroku své metody pak Aristotelés postupně ukazuje, že z takto získané perspektivy můžeme nejen pochopit důvody selhání dřive uvedených alternativních mínění, ale také odhalit jejich motivace a ukázat, v jakém ohledu mohou být částečně pravdivé. ${ }^{\mathrm{i}}$ Třetí krok tak potvrzuje převahu (a neprímo tím také pravdivost) Aristotelovy koncepce, zároveň ji však umožňuje systematicky rozvinout. Aristotelovo pojetí blaženosti tak na jedné straně vyrůstá z úvahy o lidském ergon, na druhé straně pak ze zkoumání, jak toto pojetí umožňuje porozumět běžným fenoménům a alternativním koncepcím blaženosti a štěstí.

Není cílem tohoto textu podrobně sledovat Aristotelovo rozdělení ctností na etické a rozumové a jejich podrobnou analýzu ${ }^{\mathrm{ii}}$ ani jeho úvahy o významu slasti ${ }^{\mathrm{iii}}$ a přátelstvi ${ }^{\mathrm{iv}}$ pro pro št’astný život. V souvislosti s naší otázkou se soustředíme pouze na jeden zajímavý rys Aristotelova pojetí, totiž na spojení plného uskutečnění ctnosti s tím, co

\footnotetext{
${ }^{\mathrm{i}}$ Ibid., 1098b9-1102a4.

ii Ibid., 1102a5-1145a11.

iii Ibid., 1152b1-1154b34 a 1172a16-1176a29.

iv Ibid., 1155a1-1172a15.
} 
bychom mohli nazvat „štěstím“ ve smyslu „subjektivního pocitu“ či niterného rozpoložení mysli.

Viděli jsme, že aristotelská eudaimonia neznamená primárně subjektivní (natož prchavý) pocit štěstí, ale celkovou zdařilost života. Kdybychom tedy chtěli najít nějaké užití českého slova štěstí či jeho derivátů, které by odpovídalo Aristotelově eudaimonia, pak bychom se mohli obrátit k onomu známému závěru knižního vylíčení jednoho kanonicky zdařilého života, kdy se zpoza klesající záclony zámeckého okna ozývá tichý a obdivný kněžnin povzdech „Št’astná to žena“.

Aristotelova eudaimonia tedy označuje zdařilé uskutečnění lidského „úkolu“ či „díla“, v němž člověk aktualizuje svou $\mathrm{k}$ dobru zaměřenou přirozenost. Takový plně zdařilý život je však podle Aristotela také nutně subjektivně ,„št'astný““. Aristotelés totiž svou etiku nezakládá pouze na rozlišení protikladů ctnosti a špatnosti, ale také na diferenci mezi ctností (areté) a pouhou zdrženlivostí (enkrateia) - a na analogické diferenci mezi špatností (kakia) a nezdrželivostí (akrasia). ${ }^{\text {i }} \mathrm{Na}$ rozdíl od ,pouze zdrženlivého“ si totiž plně ctnostný člověk již natolik osvojil zaměření $\mathrm{k}$ dobrému životu, že ho nemusí pokaždé znovu obtižň̌ vybojovávat proti svým protichůdným sklonům. Toto zaměření je v něm natolik habitualizováno (a „přešlo mu tedy do krve“), že v každé individuální situaci dokáže s jakousi až virtuózní

${ }^{\mathrm{i}}$ Ibid., 1145a15-1145b20. 
lehkostí, samozřejmostí, ba radostí zaujmout náležitý postoj a správně jednat.

Tento rys Aristotelova pojetí blaženosti vyvstane zvláště zřetelně, pokud ho srovnáme s Kantovými úvahami o rozdílu mezi jednáním na základě mravního zákona a na základě „přirozených náklonností“. Cílem lidského života totiž podle Aristotela není heroické mravní jednání na základě rozumově pochopené povinnosti, které se prosazuje navzdory našim „přirozeným“ sklonům, ale dosažení vnitřní jednoty, v níž již rozum natolik ,„prememluvil““ naši iracionální složku, že mu nejen neklade odpor, ale že mu pomáhá v jednotlivých konkrétních situacích bezprostředně „,vidět“ př́ležitost $\mathrm{k}$ uskutečnění zdařilého života a bez klopýtnutí a vnitřních zápasů se těchto př́ležitostí činně chopit a realizovat je. Proto také dokonalé blaženosti podle Aristotela nikdy nechybí slast, pochopená jako završení ničím nerušené a bez překážek se uskutečňující aktualizace lidské přirozenosti a jejích potencialit. ${ }^{\mathrm{i}}$ „Št’astný život“ je tedy podle Aristotela charakterizován jak celkovou zdařilostí, tak příslušným stavem mysli, přičemž jednoty obojího lze dosáhnout pouze tehdy, když se zaměříme na celkovou zdařilost života, nikoli na subjektivní stav mysli. Jakkoli to může znít přehnaně optimisticky, ve zkratce podle Aristotela platí, že skutečně dobrý člověk žije svůj zdařilý život št'asten a rád

${ }^{\mathrm{i}}$ Ibid., 1152b1-1154b34 a 1172a16-1176a29. 


\section{Nahodilost a podíl na božském osudu}

$\mathrm{Z}$ doposud řečeného by se mohlo zdát, že Aristotelés staví své pojetí blaženosti na snad až přemrštěném předpokladu jednoty lidské přirozenosti. Člověk je sice podle něj vnitřně bohatě diferencovaná bytost, není však „občanem dvou světů“ (tedy například, tak jako u Kanta, světa prírodní determinace a přirozených sklonů na straně jedné, svobody a jednaní $\mathrm{z}$ úcty $\mathrm{k}$ zákonu na straně druhé), ani se $\mathrm{v}$ jeho nitru neskrývá nějaký základní rozkol či tragická rozpolcenost. Pokud svůj život zaměříme správným směrem, tedy na jeho celkovou zdařilost založenou na kritickém promýšlení, internalizaci a „habitualizaci“ ctností, mohou všechny naše různorodé složky, včetně naší touhy po slasti a subjektivním „štěstí“ dojít svého plného uskutečnění.

Aristotelés, tento bystrý pozorovatel mnohoznačnosti prrírodních i lidských fenoménů, je však zároveň dalek jakéhokoli naivního optimismu a jeho ctnostný člověk se ani zdaleka nepodobá bezduchému ,automatu na dokonalé jednání“. Jak je zřejmé z analýz v Poetice a dalších spisech, náš myslitel si je dobře vědom nejen nebezpečí tragického zvratu štěstí a lidského úsilí o něj v jeho protiklad, ale také velmi obtížného, ne-li neuskutečnitelného dosažení plné ctnosti a s ní související blaženosti.

Povědomí o křehkosti lidského dobra a o závislosti zdařilého života na okolnostech, nad nimiž nemáme vládu, se opakovaně navrací také v Aristotelových etických 
spisech. Jakožto smrtelní obyvatelé sublunárního světa, v němž sice nechybí řád a racionalita, v němž však vše může být také jinak, jsme nakonec $\mathrm{v}$ mnohém ohledu odkázáni na př́zeň osudu a nahodilosti. Proto také ani počátek, ani završení našeho úsilí o dobrý život nemáme plně ve své moci. Pokud jsme se např́klad narodili do otrockého postavení, či pokud se nám nedostalo náležitého vychování, jsou podle Aristotela naše možnosti žít vskutku št’astný život radikálně omezené. Také rozvinutí našich možností v dospělém věku předpokládá př́tomnost alespoň základních materiálních podmínek a „vnějších dober“ a nikdy nad ním nepřestane viset Damoklův meč životních nezdarů a katastrof. ${ }^{\mathrm{i}}$

Do zdánlivě harmonického pojetí lidského štěstí však nevnáší napětí pouze závislost na vnějších dobrech. Aristotelés se od počátku svých etických zkoumání vymezuje proti svému učiteli Platónovi a zdůrazňuje, že nehledá nějaké obecné transcendentní dobro, ale dobro lidské, uskutečnitelné v lidském životě. ${ }^{\text {ii }} \mathrm{O}$ to překvapivější může být závěr, k němuž alespoň v Etice Nikomachově dospívá. Nejvyšší blažeností totiž nakonec podle našeho filosofa není to, co je lidsky uskutečnitelné, tedy politický život v obci, ale podíl na božské blaženosti spočívající $\mathrm{v}$ theoria, tedy $\mathrm{v}$ kontemplaci a poznání toho, co je neměnné. ${ }^{i i i} \mathrm{~V}$ tomto ohledu se lidská blaženost zdá být vždy

\footnotetext{
${ }^{\mathrm{i}}$ Ibid., 1110a10-110196a21.

ii Ibid., 1096b32-1096b35.

iii Ibid., 1140b31-1145a11 a především 1177a12-1178b32.
} 
nedokonalá, nebot' svou míru i své završení nemá př́sně vzato v sobě, ale v tom, čemu se může vždy pouze blížit a připodobňovat.

\section{Jednota a mnohotvárnost štěstí}

Je tedy nakonec Aristotelovo pojetí lidské přirozenosti a lidského štěstí jednotné pouze zdánlivě? $Z$ výše řečeného je zřejmé, že si tuto jednotu nesmíme podle Aristotela představovat př́liš neproblematicky. Zároveň však platí, že Aristotelovo pojetí štěstí a blaženosti nalézá paradoxně nové potvrzení právě tam, kde by se mohlo začít třišstit. Jak nahodilost sublunárního světa, tak podíl na božském údělu, který je měřítkem a nedosažitelným úběžníkem našich životủ, ${ }^{i}$ sice totiž na první pohled narušují harmonii lidského mravního úsilí a na něm založené subjektivní „radosti“, nakonec však vedou $\mathrm{k}$ prohloubenému porozumění „štěstí“" a toho, co vše k němu patří.

Úsilí o zdařilost celého života, ale i jeho úspěch spojený $\mathrm{s}$ dosažením „subjektivního štěstí“, jsou totiž vzhledem k nahodilosti našeho světa ještě v jiném smyslu závislé na „štěstí“. Neobejdou se totiž bez „št’astného řízení osudu“. Plně dobrý lidský život by tak byl podle Aristotela št'astný ve trojím smyslu: (1) byl by zdařilým uskutečněním lidského ergon; (2) provázel by ho ,št’astný“" stav mysli; a nechyběl by mu (3) ani prvek štěstí ve smyslu ,fortuny“,

\footnotetext{
${ }^{\mathrm{i}}$ Ibid., $1177 \mathrm{~b} 26-1178 \mathrm{~b} 32$.
} 
této zvláštní kombinace „št’astné náhody“ a podílu na božském ř́zení. ${ }^{\mathrm{i}}$

Aristotelés tak svým pojetím eudaimonia (tedy životní zdařilosti, subjektivního štěstí i „př́tomnosti dobrého daimóna", jak bychom také mohli toto řecké slovo přeložit) nejen pokrývá tři základní významy slova „štěstí“ (štěstí jako „fortuna a „št’astná náhoda“; štěstí jako „subjektivní deskriptivní stav mysli“; a „štěstí“ jako hodnotící charakteristika zdařilého života, vystavená kritickému přezkoumání druhých), ale naznačuje také jejich vzájemný vztah. Ačkoli totiž št’astný a zdařilý život není nikdy plně v naší moci, je možný výhradně na základě našeho dlouhodobého úsilí o uskutečnění ctnosti v médiu našeho tělesného, do značné míry animálního a stálým zajišt’ováním nejrůznějších potřeb zatíženého života. A štěstí jako subjektivní pocit je sice známkou plně zdařilého života, lze ho však dosáhnout pouze tehdy, když není primárním cílem našeho snažení, ale když k němu přistupuje takřka „mimochodem“ jako jakýsi návdavek a št’astné završení, které není nikdy plně v našich silách a které nám ve své vrcholné podobě nepř́sluší jinak, než jako letmý dotyk čehosi božského a vzdáleného.

Podle Aristotela jsme tedy komplexní „animálně-racionální bytosti“, které v sublunární sféře charakterizované nahodilostí uskutečňují to, co je vposledku božské. Aristotelovo široké a vnitřně diferencované pojetí štěstí tak

\footnotetext{
${ }^{\mathrm{i}}$ Ibid., 1179a22-32.
} 
do sebe zahrnuje jak mravní nárok a vážnost lidského úsilí, tak niterný stav mysli i vydanost lidské snahy silám, jež nemáme $\mathrm{v}$ moci. Ruku $\mathrm{v}$ ruce $\mathrm{s}$ touto předností Aristotelova širokého pojetí štěstí a blaženosti však jde také jedna jeho slabina. Ačkoli totiž Aristotelés nabízí hlubokou analýzu přátelství a „politického“ rozměru lidských životů, skutečný ohled na utrpení a neštěstí druhých zůstává stranou jeho hlavního zájmu. Jakoby si Aristotelés nebyl vědom toho, že zdráhání, jež nám může bránit v kladné odpovědi na naši výchozí otázku (totiž zda je št'astný život mravný), nemusí vycházet pouze $\mathrm{z}$,kantovského“ předpokladu, podle něhož spolu mravnost a štěstí primárně nesouvisí, ale také $\mathrm{z}$ pochybnosti, zda si tváří $\mathrm{v}$ tváŕ všemu utrpení a bezpráví $\mathrm{v}$ našem světě vůbec smíme dovolit být $\mathrm{v}$ plném slova smyslu št'astni. Obávám se, že na tuto pochybnost, stejně tak jako na otázku, zda se nakonec prŕliš vypjaté soustředění na dosažení štěstí samo snadno nestává zdrojem neštěstí, Aristotelés přesvědčivou odpověd' nenabízí. 